\title{
MENINGKATKAN HASIL BELAJAR CHEST PASS DALAM PERMAINAN BOLA BASKET MELALUI PENDEKATAN BERMAIN
}

\author{
Henry Maksum ${ }^{1}$, Tovan Ridho Wibowo ${ }^{2}$ \\ ${ }^{1,2}$ Program Studi Pendidikan Jasmani Kesehatan dan Rekreasi \\ Fakultas Pendidikan Olahraga dan Kesehatan IKIP PGRI Pontianak \\ Jalan Ampera Nomor 88 Pontianak 78116 \\ 1e-mail: henrymaksum68@gmail.com
}

\begin{abstract}
Abstrak
Penelitian bertujuan untuk mengetahui peningkatan hasil belajar hasil belajar chest pass dalam permainan Bola Basket melalui Pendekatan Bermain. Metode yang digunakan adalah penelitian tindakan dengan bentuk penelitian tinadakan kelas (PTK). Subyek penelitiannya siswa kelas X SMA Negeri 1 Sintang yang terdiridari 23 siswa putri dan 12 siswa putra. Teknik pengumpulan data menggunakan observasi dan pengukuran sedangkan alat pengumpulan datanya adalah lembar observasi dan bentuk tes. Hasil penelitian memperlihatkan bahwa melalui metode pendekatan bermain dapat meningkatkan kemampuan chest passdarites yang diberikan, yaitunilai rata-rata sebelum menggunakan pendekatan bermain yaitu $43 \%$ tuntas dan $57 \%$ belum tuntas, setelah menggunakan pendekatan bermain pada siklus I hasil belajar meningkat menjadi 63\% siswa yang tuntas dan $37 \%$ siswa belum tuntas, pada siklus II dengan perlakuan yang sama terjadi peningkatan menjadi $80 \%$ siswa yang tuntas dan hanya tersisa $20 \%$ siswa yang belum tuntas. Artinya bahwa terdapat peningkatan hasil belajar chest pass bola basket dengan menggunakan pendekatan bermain.
\end{abstract}

Kata Kunci: pembelajaran bola basket, pendekatan bermain.

\begin{abstract}
The study aims to determine the improvement in learning outcomes of chest pass learning outcomes in Basketball games through the Play Approach. The method used is action research with the form of first-class research (CAR). The research subjects were class X students of Sintang 1 Public High School consisting of 23 female students and 12 male students. Data collection techniques use observation and measurement while the data collection tools are observation sheets and test forms. The results of the study show that through the play approach method can increase the ability of chest pass from the given test, that is, the average value before using the play approach which is $43 \%$ complete and $57 \%$ not yet completed, after using the play approach in the first cycle learning outcomes increased to $63 \%$ of students who completed and $37 \%$ of students not yet completed, in the second cycle with the same treatment an increase occurred to $80 \%$ of students who completed and only $20 \%$ of students who have not finished.This means that there is an increase in basketball chest pass learning outcomes using the play approach.
\end{abstract}

Keywords: basketball learning, approach to play. 


\section{PENDAHULUAN}

Bola basket merupakan salah satu cabang olahraga yang di gemari oleh masyarakat, baik di Indonesia maupun dunia. Permainan bola basket modern merupakan jenis permainan yang begitu cepat perkembangannya dan menarik perhatian manusia pada umumnya dan pemuda pada khususnya. Perkembangan permainan bola basket di Indonesia semakin hari semakin menunjukkan tingkat kemampuan yang pesat.

Berbagai macam peraturan telah bannyak mengalami perubahan. Perubahan seperti diketahui permainan bola basket merupakan olahraga yang di mainkan oleh dua regu berlawanan dan setiap regu terdiri dari lima pemain, sedangkan pemain pengganti sebannyak tujuh orang jadi tiap regu paling bannyak terdiri dari 12 orang pemain. Permainan bola basket dimainkan di atas lapangankeras yang sengaja diadakan untuk itu, baik di lapangan terbuka maupun diruangan tertutup. Permainan bola basket merupakan kerjasama tim dan keterampilan individu di dalamnnya terkandung unsur yang diperlukannya, yakni kekuatan daya tahan, kecepatan, ketepatan, dan power. Sedangkan untuk keterampilan individu pemain bola basket wajib menguasai teknik dasar permainan bola basket yakni mengopor dan menagkap (passing/couthing), menggiring bola (dribbling), serta menembak (shoting). Pada umumnya permainan bola basket di tuntut untuk menguasai teknik dasar bermain. Teknik dasar yang baik dan benar menentukan keberhasilan seseorang untuk pengembangan dirinya pada teknik yang lebih tinggi.

Teknik-teknik tersebut yang paling penting dalam permainan bola basket adalah Chestpass. Chestpass merupakan salah satu bagian terpenting dari setiap tim bola basket untuk melakukan penyerangan. Ambler (2006: 11) mengemukakan bahwa keterampilan terpenting dalam permainan bola basket ini ialah kemampuan untuk chestpass atau mengoper bola dalam dengan rekan satu tim, keterampilan ini merupakan suatu keterampilan yang memberikan hasil nyata secara langsung. Dalam hal ini chestpass sangat berpengaruh dalam permainan bola basket karna yang menentukan kompak tidaknya permainan tim dalam satu sehingga mendapatkan hasil yang maksimal dalam pertandingan, oleh sebab itu 
chestpass sangat berpengaruh dalam permainan bola basket. Mengoper (chestpass) yang baik bagi permaianan tim dan memiliki keahlian akan membuat bola basket menjadi permainan tim yang indah. Disamping itu dengan memiliki dan menguasai berbagai tehnik Chestpass ini akan membuka kesempatan mengolah bola sehingga terbuka kesempatan melaksanakan operan (chestpass) kearah rekan satu tim.

Perkembangan strategi menyerang dalam permainan bola basket saatini pun meningkat dengan pesat. Berbagai jenis operan/passing sebagai strategi menyerang Oliver (2004), menyatakan bahwa jumlah macam passing atau operan adalah sama passing dengan cara dipantulkan (bouncepass), operan dari atas kepala (overheadpass). Dalam chestpass bola basket diperlukan kejelihan serta ketepatan yang mendorong bola sampai kerekan satu tim.

Berdasarkan pengamatan di Sekolah Menengah Atas Negeri 1 Sintang, diketahui bahwa keterampilan siswa dalam bermain bola basket masih terbatas. Banyak siswa mengalami kesulitan dalam memahami materi bola basket baik teori maupun praktik terutama pada kemampuan melakukan teknik dasar chestpass. Faktor penyebab terjadinya masalah tersebut diantaranya siswa kurang memahami penjelasan dari guru yang tidak menciptakan suasana pembelajaran yang menyenangkan serta rendahnya kemampuan siswa pada permainan bola basket terutama materi chestpass sehingga mempengaruhi hasil belajar siswa. Berdasarkan wawancara dengan guru penjaskes, nilai rata-rata siswa belum mencapai Kriteria Ketuntasan Minimal (KKM) yaitu sebesar 70. Jika dilihat dari nilai siswa, sebanyak 15 siswa dari 35 siswa yang sudah mencapai ketuntasan (43\%), sedangkan sebanyak 20 siswa masih dibawah KKM yang ditetapkan oleh sekolah (57\%). Hal ini menunjukkan bahwa masih lemahnya pemahaman siswa dalam materi chestpass.

Oleh karena itu, perlu adanya inovasi baru dalam pembelajaran khususnya pada materi chestpass. Pembelajaran yang monoton menggunakan metode ceramah dan demontrasi dalam menyampaikan materi pembelajaran diubah dengan menggunakan metode pendekatan bermain. Menurut Pontjopoetro (2004), bermain adalah belajar menyesuaikan diri dengan keadaan anak-anak bermain 
dalam daerah sekelilingnya dan dengan barang dalam daerah itu. Guru pendidikan jasmani masih sangat terbatas dalam menggunakan metode pendekatan bermain sebagai inovasi dalam pembelajaran pendidikan jasmani. Sehinggamenjadi malas dalam menuangkan kreativitas dalam megajar, padahal menggunakan metode pendekatan bermain sebagai metode pembelajaran sangatlah membantu guru pendidikan jasmani dalam menyampaikan materi, dan siswa juga lebih fokus ketika mengikuti proses belajar karna siswa bisa ikut melihat secara langsung. Olahraga di sekolah di pandang sebagai alat pendidikan yang mempunyai peran penting terhadap pencapaian tujuan belajar mengajar secara keseluruhan, untuk itu diperlukan sebuah inovasi dan pengembangan. Berdasarkan pemaparan ini, peneliti tertarik untuk menerapkan metode pendekatan bermain sebagai inovasi dalam pembelajaran dengan harapan siswa mampu melakukan teknik dasar chestpass dengan baik dan benar.

Berdasarkan masalah dan uraian diatas maka peneliti tertarik melakukan penelitian dengan judul "Upaya Meningkatkan Hasil Belajar Chest pass Dalam Permainan Bola Basket Melalui Metode Pendekatan Bermain Pada Siswa Kelas X MIPA 1 Sekolah Menengah Atas Negeri 1 Sintang”.

\section{METODE}

Penelitian ini termasuk penelitian pengembangan dengan metode penelitian tindakan kelas yaitu upaya meningkatkan kemampuan chest passbola basket melalui pembelajaran pendekatan bermain pada siswa kelas X SMA Negeri 1 Sintang. Arikunto, (2006: 96) menjelaskan penelitian tidakan kelas adalah penelitian yang dilakukan oleh guru dikelas atau di sekolah tempat ia mengajar dengan penekanan pada penyempurnaan atau peningkatan proses dan praktis pembelajaran. Berkaitan dengan penelitian tindakan kelas (PTK) Kristiyanto (2011: 32) mengatakan bahwa penelitian tindakan kelas adalah suatu bentuk kajian yang bersifat reflektif dan dilakukan untuk meningkatkan kemampuan rasional dari tindakan-tindakan guru dalam melaksanakan dan memperdalam pemahaman terhadap tindakan yang dilakukan, serta memperbaiki kondisi dimana 
praktek pembelajaran jasmani dilakukan, dimulai dari adanya perencanaan, pelaksanaan, observasi dan refleksi untuk setiap siklusnya.

Subjek penelitian ini adalah kelas X SMAN 1 Sintang yang terdiri dari 12 laki-laki dan 23 perempuan dan berkolaborasi dengan 1 (satu) guru Penjaskes. Teknik pengumpulan data dalam penelitian ini yaitu: 1) Teknik Observasi Langsung adalah teknik pengumpulan data dengan mengadakan pengamatan langsung terhadap guru. Sejalan dengan pendapat Sugiyono (2011:226) bahwa “observasi adalah dasar semua ilmu pengetahuan. Para Ilmuwan hanya dapat bekerja berdasarkan data, yaitu fakta mengenai dunia kenyataan yang diperoleh melalui observasi”. Dengan demikian, bahwa observasi merupakan salah satu metode untuk mendapatkan data. Dalam pengumpulan data diperlukan panduan observasi sebagai daftar pengecek dalam mengamati perancanaan dan pelaksanaan pembelajaran chest pass bola basket melalui pendekatan bermain dilakukan guru. Sedangkan tes dalam penelitian ini untuk mengukur kemampuan chest pass. Dalam penelitian ini akan dilakukan analisis data secara kualitatif berdasarkan hasil observasi dan refleksi serta analisis data. Untuk menjawab rumusan penelitian adalah sebagai berikut: 1) Rumusan masalah pertama dan kedua dianalisis dengan deskriftif naratif (data kualitatif), dan 2) Rumusan masalah ketiga dianalisis dengan statistic deskriptif (persentase).

Melalui Penelitian ini diharapkan dapat meningkatkan kemampuan chest pass dalam permainan bola basket melaluipendekatanbermain pada siswakelas $\mathrm{X}$ SMA Negeri 1 Sintang. Hal ini ditandai dengan adanya peningkatan presentase ketuntasanbelajarsiswa setelah tindakan jika dibandingkan dengan sebelum tindakan melalui hasil observasi. Indikator penelitian ini meliputi: 1) Kemampuan guru merencanakan, melaksanakan dan mengevaluasi dalam kegiatan pembelajaran pasing bawah melalui strategi latihan berpasangan; 2) Kemampuan siswa dalam melakukan chest pass meningkat setelah guru menggunakan pendekatan bermain. 


\section{HASIL DAN PEMBAHASAN}

\section{Deskripsi Kondisi Awal Prasiklus}

Pada awal sebelum pelaksanaan tindakan peningkatan kemampuan chest pass bola basket melalui pendekatan bermain masih sangat kurang hal ini dapat dilihat dari observasi awal dimana guru dalam memberikan pembelajaran passing bawah bola voli mini metode yang digunakan masih dengan cara-cara lama yaitu diawali metode ceramah disertai demonstrasi dengan memberikan contoh-contoh gerakan dilanjutkan dengan penugasan-penugasan. Metode atau cara tersebut dilakukan dengan asal-asalan belum sesuai dengan petunjuk benar. Sehingga siswa pada saat di tes kemampuan masih banyak memperoleh nilai di bawah criteria ketuntasan minimal (KKM) dari yang telah ditetapkan di sekolah 75. Hasil tes chest pass dari prasiklus atau kondisi awal diperoleh rata-rata $43 \%$ tuntas dan $57 \%$ belum tuntas, setelah menggunakan pendekatan bermain pada siklus I hasil belajar meningkat menjadi $63 \%$ siswa yang tuntas dan $37 \%$ siswa belum tuntas, pada siklus II dengan perlakuan yang sama terjadi peningkatan menjadi $80 \%$ siswa yang tuntas dan hanya tersisa20 \% siswa yang belum tuntas. Artinya bahwa terdapat peningkatan hasil belajar chest pass bola basket dengan menggunakan pendekatan bermain.

Tabel 1 Distribusi Frekuensi Tes Hasil belajar chest pass dalam permainan bola basket Prasiklus

\begin{tabular}{cccc}
\hline Interval & $\begin{array}{c}\text { Frekuensi } \\
\text { Absolut }\end{array}$ & $\begin{array}{c}\text { Frekuensi } \\
\text { Relatif }\end{array}$ & Frekuensi Komulatif \\
\hline $56-59$ & 8 & 22,86 & 22,86 \\
\hline $60-63$ & 4 & 11,43 & 34,29 \\
\hline $64-67$ & 8 & 22,86 & 57,15 \\
\hline $68-71$ & 0 & 0 & 57,15 \\
\hline $72-75$ & 15 & 42,85 & 100 \\
\hline & $\mathbf{3 5}$ & $\mathbf{1 0 0}$ & \\
\hline
\end{tabular}

Berdasarkan data hasil distribusi frekuensi prasiklus pada Tabel 1, diketahui bahwa terdapat 8 orang siswa dengan nilai rentang interval $56-59$, 
4orang siswa dengan rentang interval $60-63,8$ orang siswa dengan rentang interval $64-67,0$ orang siswa dengan rentang interval $68-71,15$ siswa dengan rentang interval $72-75$.

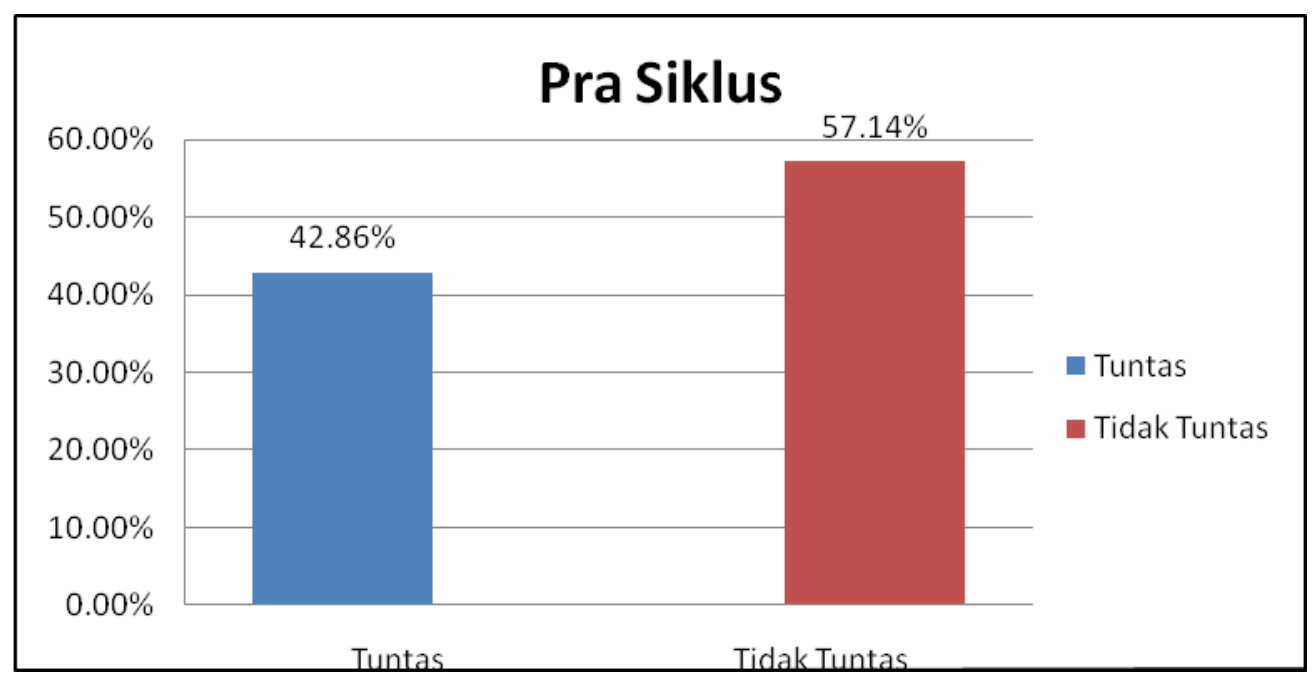

Gambar 1 Grafik Kondisi Awal

Berdasarkan hasil observasi pra siklus, diketahui bahwa hanya ada beberapa siswa yang sudah lulus dalam mengikuti pembelajaran chest pass dalam permainan bola basket sesuai dengan indikator ketercapaian yang telah direncanakan sebelumnya., dari jumlah 35 tercatat hanya 15 siswa atau 42,86\% yang tuntas dalam mengikuti pembelajaran chest pass dalam permainan bola basket dan 20 siswa atau 57,14\% lainnya belum masuk kriteria tuntas.

\section{Deskripsi Data Siklus I}

Presentasi ketuntasan hasil tes hasil belajar chest pass dalam permainan bola basket padasiklus I dapat dilihat pada tabel 2 .

Tabel 2 Distribusi Frekuensi Hasil belajar Chest pass dalam permainan bola basket siklus I

\begin{tabular}{cccc}
\hline $\begin{array}{c}\text { Interval } \\
\text { Kelas }\end{array}$ & $\begin{array}{c}\text { Frekuensi } \\
\text { Absolut }\end{array}$ & $\begin{array}{c}\text { Frekuensi } \\
\text { Relatif }\end{array}$ & Frekuensi Komulatif \\
\hline $61-64$ & 9 & 25,71 & 25,71 \\
\hline $65-68$ & 4 & 11,43 & 37,14 \\
\hline $69-72$ & 8 & 22,86 & 60 \\
\hline $73-76$ & 0 & 0 & 60 \\
\hline $77-80$ & 14 & 40 & 100 \\
\hline & $\mathbf{3 5}$ & $\mathbf{1 0 0}$ & \\
\hline
\end{tabular}


Berdasarkan data hasil distribusi frekuensi siklus I di atas maka diperoleh nilai rentang interval 61-64 terdapat 9 siswa, rentang interval 65-68 terdapat 4 siswa, rentang interval 69-72 terdapat 8 siswa, rentang interval 73-76 terdapat 0 siswa, rentang interval 77-80 terdapat 14 siswa.

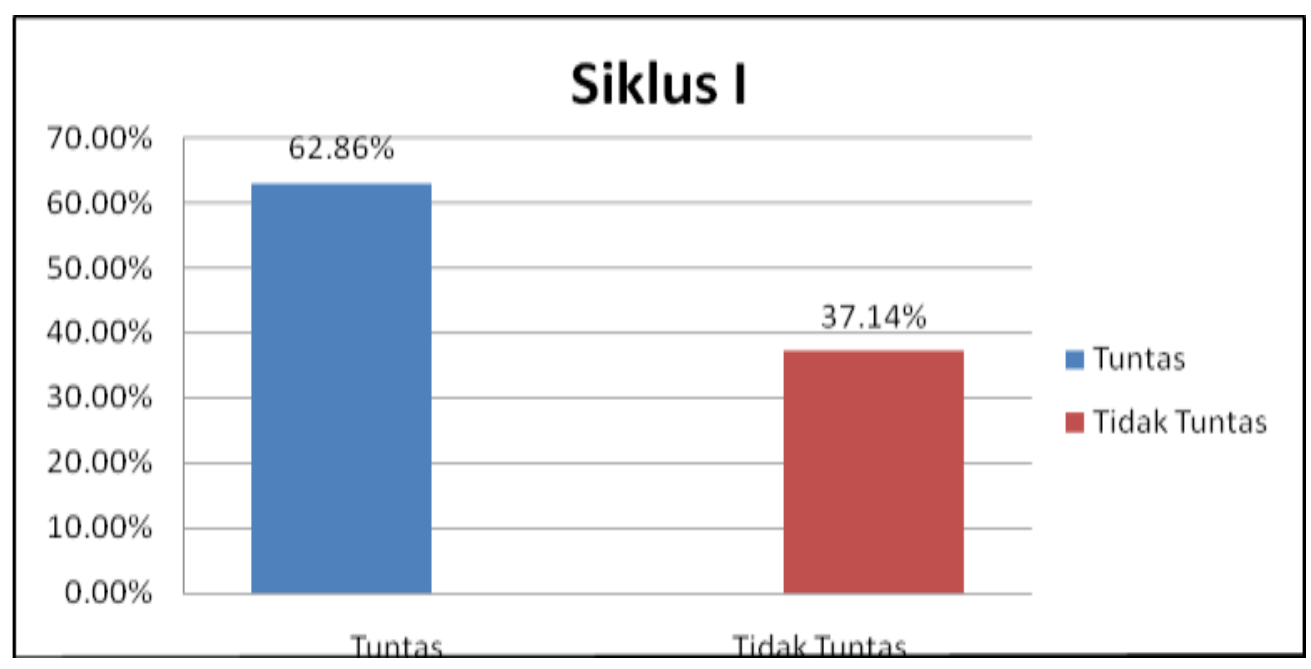

Gambar 2 Grafik Siklus I

Berdasarkan gambar 2, diketahui bahwa dari jumlah 35 siswa tercatat ada 22 siswa atau $62,86 \%$ yang tuntas dan 13 siswa atau $37,14 \%$ belum masuk kriteria tuntas. Hal ini menunjukkan bahwa adanya kenaikan jumlah siswa yang tuntas setelah diberikan perlakuan pada siklus 1 .

\section{Deskripsi Data Siklus II}

Presentasi ketuntasan hasil tes tes proses hasil belajar chest pass dalam permainan bola basket pada siklus II dapat dilihat pada tabel 3 .

Tabel 3 Distribusi Frekuensi Tes Hasil belajar chestpass Siklus II

\begin{tabular}{cccc}
\hline Interval Kelas & $\begin{array}{c}\text { Frekuensi } \\
\text { Absolut }\end{array}$ & $\begin{array}{c}\text { Frekuensi } \\
\text { Relatif }\end{array}$ & Frekuensi Komulatif \\
\hline $67-70$ & 7 & 20 & 20 \\
\hline $71-74$ & 6 & 17,143 & 37,143 \\
\hline $75-78$ & 9 & 25,714 & 62,857 \\
\hline $79-82$ & 0 & 0 & 62,857 \\
\hline $83-86$ & 13 & 37,143 & 100 \\
\hline & $\mathbf{3 5}$ & $\mathbf{1 0 0}$ & \\
\hline
\end{tabular}

Berdasarkan data hasil distribusi frekuensi siklus II di atas maka diperoleh nilai rentang interval 67-70 terdapat 7 siswa, rentang interval 71-74 terdapat 6 
siswa, rentang interval 75-78 terdapat 9 siswa, rentang interval 79-82 terdapat 0 siswa, rentang interval 83-86 terdapat 13 siswa.

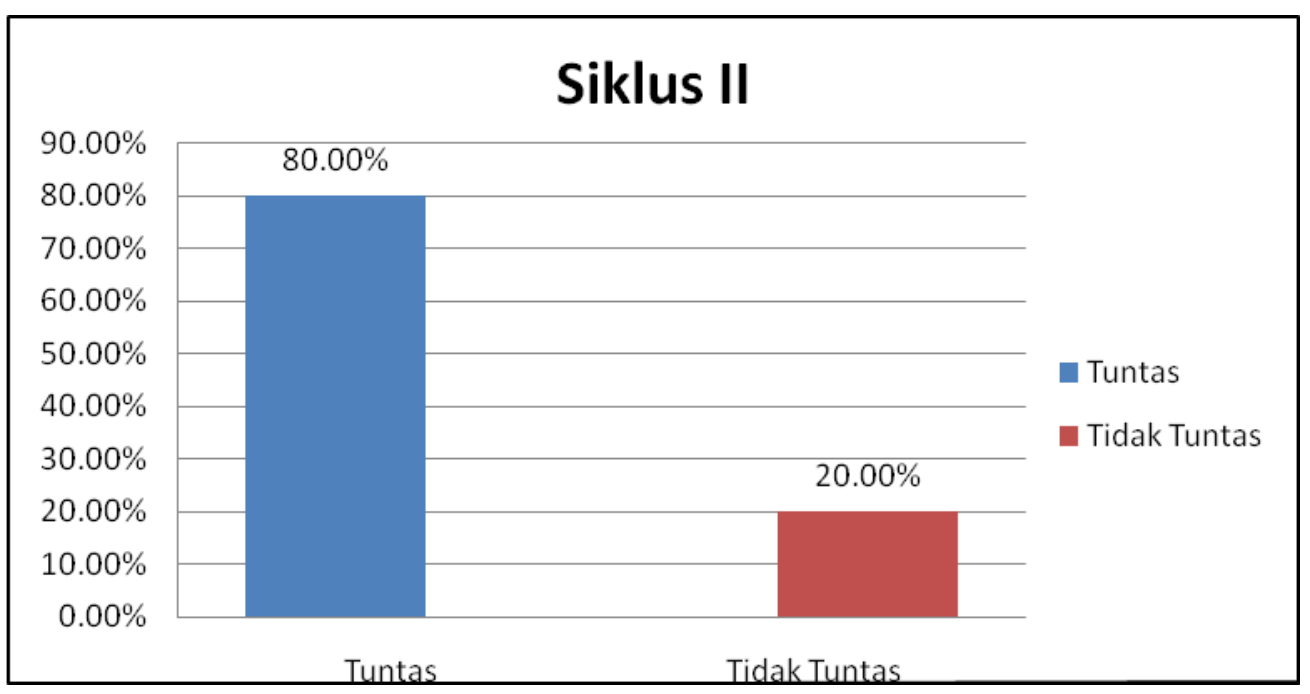

Gambar 3 Grafik Siklus II

Berdasarkan hasil belajar pada siklus II diatas maka diperoleh persentase siswa. Dari jumlah 35 siswa tercatat ada 28 siswa atau $80 \%$ yang tuntas dan 7 siswa atau $20 \%$ belum masuk kriteria tuntas.

\section{Siklus I}

\section{Perencanaan tindakan}

Kegiatan perencanaan tidakan siklus I dilaksanakan pada hari senin 25 Juni 2018, di Kelas X MIPA 1 Sekolah Menengah Atas Negeri 1 Sintang, peneliti dan guru pendidikan jasmani yang bersangkutan mendiskusikan rancangan tindakan yang akan dilakukan dalam proses penelitian ini, seluruh rencana pada tindakan siklus I termuat dalam rencana pelaksanaan pembelajaran ( RPP ) siklus I, melalui RPP siklus I tersebutmaka di sepakati bahwa pelaksanaan tindakan pada siklus I diadakan selama dua kali pertemuan.

Berdasarkan hasil observasi terhdap proses pembelajaran dan hasil belajar sebelum tindakan, dapat diperoleh sebagai data awal. Hasil pencatatan menunjukan bahwa dari siswa Kelas X MIPA 1 Sekolah Menengah Atas Negeri 1 Sintang tahun ajaran 2018 sebanyak 35 siswa, terdapat 20 siswa yang masih belum mencapai batas ketuntasan belajar. 
Melalui hasil pengukuran tersebut maka peneliti dan guru merancang rencana pelaksanaan tindakan siklus I sebagai berikut: (1) Peneliti dan guru merancang scenario pembelajaran dengan menggunakan metode pendekatan bermain, meningkatkan hasil belajar chest pass dalampermainan bola basket; (2) Peneliti dan guru menyusun Rencana Pelaksanaan Pembelajaran (RPP) Chest pass dalam permainan bola basket; (3) Peneliti dan guru menyiapkan alat yang akan digunakan dalam pelaksanaan proses pembelajaran chest pass dalam permainan bola basket seperti,alat-alat yang digunakan dalam permainan; dan (4) Peneliti dan guru menyusun standar penilaian pada hasil belajar Chest pass dalam permainan bola basket.

\section{Pelaksanaan}

Tahap pelaksanaan siklus I dilaksanakan pada hari rabu tanggal27 Juni 2018. Pada pertemuan pertama ini, guru sebagai penyampai materi pembelajaran sesuai dengan langkah-langkah yang sudah dibuat dan disesuaikan sebelumnya pada saat berdiskusi dengan peneliti, sedangkan tugas peneliti dalam hal ini adalah sebagai pengamat dan membantu guru dalam mempersiapkan segalanya yang berkaitan dengan hal-hal apa yang di perlukan dalam proses pembelajaran. Perlakuan dilaksanakan sebanyak dua pertemuan.

\section{Observasi}

Pembelajaran chest pass dalam permainan bola basket dengan metode pendekatan bermain pertemuan pertama pada hari rabu 27 Juni 2018 yang berlangsung selama $2 \times 45$ menit. Pada pertemuan kedua dilaksanakan pada hari Rabu 4 Juli 2018. Pembelajaran chest pass dalam permainan bola basket dengan metode pendekatan bermain .

Berdasarkan hasil observasi pengamatan langsung terhadap aktivitas guru dalam melaksanakan pengajaran pada siklus I, didapatlah data bahwa guru sudah melaksanakan pembelajaran sesuai dengan yang direncanakan. Namun ada beberapa hal yang harus diperbaiki ketika penerapan pembelajaran dilakukan. Hal yang dimaksud dapat dilihat dari data hasil observasi proses pembelajaran chest pass dalam permainan bola basket dengan metode pendekatan bermain yang sudah dilaksanakan sebagai berikut: (a) Guru meminta siswa menyiapkan alat-alat 
yang menunjang pembelajaran seperti bola, lapangan, sehingga beberapa siswa terlambat mengikuti kegiatan pembelajaran dan menyebabkan siswa tersebut tidak mengetahui apa yang dijelaskan guru sebelumnya; (b) guru belum memberikan pemanasan berupa permainan yang dapat meningkatkan semangat dan minatsiswa dalam mengikuti pembelajaran; (c) hasil tes siswa.

Berdasarkan hasil pengamatan terhadap proses hasil belajar dan hasil belajar chest pass dalam permainan bola basket dengan metode pendekatan bermain pada siswa Kelas X MIPA 1 Sekolah Menengah Atas Negeri 1 Sintang.

\section{Refleksi}

Berdasarkan hasil pengamatan dan analisis data lembar observasi terhadap proses pembelajaran yang telah dilakukan pada siklus I dapat dikemukakan dapat data hasil penelitian dari kualitas pembelajaran yang telah dilaksanakan dengan materi yang disampaikan yaitu sikap chest pass dalam permainan bola basket dengan metode pendekatan bermain, masih belum berjalan dengan optimal. Dalam hal ini, refleksi ini dilakukan oleh peneliti dan guru adalah untuk memperbaiki segala bentuk kekurangan-kekurangan yang terjadi pada siklus I untuk selanjutnya dapat diterapkan pada siklus berikutnya dengan segala bentuk penyempurnaan yang dilakukan. Adapun hal-hal yang harus diperbaiki pada siklus selanjutnya adalah sebagai berikut: (1) untuk menghindari adanya siswa yang terlambat dalam mengikuti pembelajaran guru menyiapkan segala bentuk hal yang membantu dalam proses pembelajaran yaitu hasil belajar chest pass dalam permainan bola basket; (2) guru memberikan pemanasan yang lebih menarik yaitu berupa permainan yang dapat menumbuhkan semangat percaya diri siswa dalam mengikuti pembelajaran.

\section{Siklus II}

\section{Perencanaan tindakan siklus II}

Kegiatan perencanaan ini dilakukan pada hari Senin tanggal 9 Juli 2018 pada penerapan siklus II ini, nantinya pelakasanaannya sendiri sama dengan siklus I, dimana peneliti bertindak sebagai observer (pengamat), siswa dan guru sebagai objek, sama dengan siklus I , pada siklus II ini masih terdiri atas empat tahapan yaitu: perencanaan, pelaksanaan tindakan, observasi, dan refleksi. Sebelum 
melaksanakan pada siklus II ini, peneliti dan guru mendiskusikan rencana penelitian yang disepakati akan dilaksanakan dalam 2 kali pertemuan.

Pada tahap perencanaan ini peneliti menyampaikan hasil observasi yang dilakukan pada siklus I, dimana kekurangan-kekurangan pada siklus I akan diperbaiki pada siklus II. Untuk mengatasi berbagai kekurangan yang ditemukan pada siklus I, peneliti dan guru bersepakat dalam upaya melakukan perbaikan pada siklus II.

\section{Pelaksanaan pada siklus II}

Pelaksanaan siklus II dilaksanakan pada hari Rabu 11 Juli 2018.Pada pertemuan kedua dilaksanakan pada hari Rabu 18 Juli 2018. Dalam hal ini tugas peneliti sebagi pengamat dan membantu mempersiapkan segala perlengkapan dalam proses belajar mengajar. Sesuai dengan perencanaan sebelumnya.

\section{Observasi}

Siklus II dilaksanakan sesuai rencana yaitu 2 kali pertemuan, masingmasing pertemuan terdiri dari 2 jam pelajaran atau $2 \times 45$ menit. Adapun fokus dan informasi yang peneliti lakukan adalah pada situasi pelaksanaan pembelajaran, kegiatan yang dilakukan guru ketika memberikan pembelajaran dan tes hasil belajar Chest pass dalam permainan bola basket yang dilakukan siswa ketika pembelajaran berlangsung.

Pada tahap pengamatan ini dilakukan pada saat berlangsungnya proses tindakan tersebut. Tujuan pengamatan ini mengungkapkan berbagai hal yang terjadi ketika tindakan tersebut berlangsung baik itu sebelum tindakan, maupun pada saat prasiklus tindakan itu sendiri. Proses pembelajaran yang terjadi pada pelaksanaan tindakan siklus II berjalan dengan baik. Hal ini tampak pada tindakan siswa yang semakin terlihat bersemangat dan tertib dalam mengikuti proses pembelajaran chest pass dalam permainan bola basket dengan menggunakan metode pendekatan bermain dibandingkan dengan pembelajaran yang dilakukan pada siklus I.

\section{Refleksi}

Refleksi adalah kegiatan akhir dari proses pembelajaran yang telah dilakukan. Kegiatan refleksi dilakukan berdasarkan pada hasil pengamatan dan 
hasil tes hasil belajar chest pass dalam permainan bola basket yang telah dilakukan siswa. Adapun hal-hal yang perlu direfleksi adalah secara umum kelemahan dan kekurangan yang terdapat dalam pembelajaran chest pass dalam permainan bola basket dengan menggunakan metode pendekatan bermain pada siklus I telah dapat diperbaiki pada siklus II. Peneliti dan kolaborator telah berhasil dalam melaksanakan pembelajaran dengan metode pendekatan bermain. Guru telah mampu membimbing dan membangkitkan semangat siswa dalam proses pembelajaran chest pass dalam permainan bola basket, hal terlihat pada proses pembelajaran berlangsung siswa lebih aktif dan antusias. Dengan adanya variasi pembelajaran ini yang belum pernah diterapkan guru sebelumnya terkait materi chest pass dalam permainan bola basket ini membuat siswa tertarik dan senang mengikuti pembelajaran sehingga hasil belajar siswa pun memuaskan. Sedangkan refleksi hasil belajar guru dalam melaksanakan proses pembelajaran pada siklus II dapat dikatakan bahwa kegiatan pembelajaran yang telah dilakukan oleh guru sudah mencapai hasil yang maksimal dengan kata lain pembelajaran yang diharapkan sebelumnya dapat tercapai dengan baik, serta hasil yang diharapkan dalam proses pembelajaran pun dapat tercapai. Berdasarkan refleksi yang dilakukan pada siklus II ini, didapatlah bahwa guru sudah melaksanakan tugasnya dengan sangat baik, hal ini diperjelas dengan hasil observasi aktivitas guru dalam memberikan pembelajaran di kelas sudah mengalami peningkatan.

\section{SIMPULAN}

Berdasarkan hasil penelitian dan pembahasan yang telah diuraikan, maka kesimpulan penelitian adalah: (1) sebelum melakukan tindakan melalui pendekatan bermain, hasil belajarsiswa melakukan chest pass dalam permainanbola basket pada siswa siswa kelas X SMA Negeri 1 Sintang, menunjukkan rata-rata 42,86\%; (2) setelah melakukan tindakan melalui pendekatan bermain, hasil belajar siswa melakukan chest pass dalam permainan bola basket pada siswa siswa kelas X SMA Negeri 1 Sintang, menunjukkan ratarata $63 \%$ pada siklus I dan rata-rata $80 \%$ pada siklus II; (3) terdapat peningkatan hasil belajar melakukan chest pass dalam permainan bola basket melalui 
pendekatan permainan pada siswa kelas X SMA Negeri 1 Sintang dilihat dari hasil belajar dimulai dari pra-tindakan, siklus I, dan siklus II.

\section{DAFTAR PUSTAKAN}

Ambler, V. 2008. Petunjuk untuk Para Pelatih dan Pemain Bola Basket. Bandung: Pionir.

Arikunto, S. 2006. Prosedur Penelitian Suatu Pendekatan Praktek. Jakarta: RhinekaCipta

Oliver, J. 2004. Dasar-Dasar Bola Basket. Bandung :Pakar Raya.

Sugiyono. 2008. Metode Penelitian Kuantitatif, dan R\& D. Bandung: Alfabeta

Pontjopoetro, S. 2004. Permainan Anak Tradisional dan Aktivitas Ritmik. Jakarta: Universitas Terbuka. 